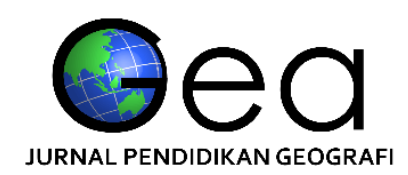

\title{
INTENSITAS KONSUMSI PANGAN LOKAL SUMBER KARBOHIDRAT NON BERAS DALAM UPAYA DIVERSIFIKASI PANGAN DI DESA HARGOREJO KECAMATAN KOKAP KABUPATEN KULON PROGO
}

\author{
Mohamad Deden Mutakin \\ Program Pascasarjana Fakultas Geografi Universitas Gadjah Mada Yogyakarta \\ dedenmutakin@mail.ugm.ac.id
}

\begin{abstract}
ABSTRAK
Upaya penganekaragaman konsumsi pangan lokal sumber karbohidrat dapat mengurangi tekanan pada ketersediaan satu macam produk pangan. Mengkosumsi pangan lokal sumber karbohidrat non beras serapan energi dan protein dapat sesuai dengan angka yang dianjurkan. Berdasarkan hal itu, peneltian yang melibatkan rumahtangga non tani dan tani Dusun Selo Timur dan Ngulakan Desa Hargorejo Kecamatan Kokap dilakukan untuk menganalisis intensitas konsumsi pangan lokal sumber karbohidrat non beras dalam pemenuhan energi dan protein sesuai angka yang dianjurkan pola pangan harapan WKNPG VIII 2004 dan melihat sejauh mana upaya masyarakat dalam usaha pencapaian ketahanan pangan melalui diversifikasi pangan sumber karbohidrat rumahtangga non tani dan tani. Dengan metode multistage sampling didapatkan sampel sebanyak 120 orang. Berdasarkan telaah dapat disimpulkan rumahtangga non tani dan tani belum menerapkan diversifikasi pangan dalam konsumsi sehari-hari. Intensitas konsumsi pangan lokal sumber karbohidrat non beras masih sangat rendah atau belum sesuai dengan angka yang dianjurkan.
\end{abstract}

Kata kunci: intensitas konsumsi, pangan lokal sumber karbohidrat non beras

\begin{abstract}
This research aimed to analyze the intensity of consumption of local food sources of carbohydrates non-rice in the fulfillment of energy and protein according to the number recommended dietary pattern hope WKNPG VIII 2004 and to see the extent of community efforts in diversification efforts carbohydrate source non-farm household and farm in the hamlet of East and Ngulakan Selo Village Hargorejo District Kokap. By multistage sampling method and Slovin formula obtained a sample of 120 people. Based on the review concluded non-farm households and farmers are not applying food diversification in daily consumption. The intensity of consumption of local food sources of carbohydrates non-rice is still very low or not in accordance with the recommended figure.
\end{abstract}

Keywords: intensity of consumption, local food sources of carbohydrates non-rice

\section{PENDAHULUAN}

Setiap manusia memerlukan bahan makanan untuk menunjang kelangsungan hidupnya. Dengan menggunakan bahan makanan, manusia membangun sel-sel tubuhnya dan menjaganya agar tetap dan berfungsi sebagaimana mestinya.
Konsumsi pangan pokok masyarakat saat ini didominasi oleh beras (Yunita dan Riswani, 2013), (Moniharapon dkk, 2013) yang menyebabkan komoditas ini satusatunya menjadi sumber karbohidrat utama bagi masyarakat Indonesia (Musriadi dkk., 2010), (Hastarini, 2010). 
Kondisi ini seolah-olah menciptakan suatu penggambaran bahwa pangan sumber karbohidraat hanya bersumber dari beras, sehingga "memaksa" pemerintah untuk selalu melakukan pengawalan ketat terhadap komoditas ini. Bahkan pemerintah tidak segan untuk melakukan impor beras hanya demi menjaga stabilitas pasokan beras. Menurut World Trade Organization impor pangan dalam jangka pendek bisa menjadi obat kelaparan namun dalam jangka panjang tidak hanya menguras devisa, tetapi mengabaian aneka sumber daya lokal (Suyastiri, 2008). Beras mempunyai kedudukan vital dan fatal. Vital, sebab beras adalah kebutuhan dasar penduduk Indonesia, sedangkan fatal apabila pasokannya defisit sehingga dapat dijadikan sebagai alat oleh kekuatan politik, baik bagi politik yang sedang berkuasa maupun tidak berkuasa (Arifin, 1997).

Dalam hal pangan, Indonesia memiliki keragaman pangan lokal yang sangat beraneka. Potensi pangan lokal ini seharusnya layak dikedepankan dalam rangka upaya diversifikasi pangan. Dengan konsumsi pangan yang beraneka maka kekurangan suatu zat gizi dalam suatu pangan dapat ditutupi oleh kelebihan zat gizi dalam pangan lain, sehingga kelengkapan zat gizi dan kuantitas yang diperlukan tubuh dapat lebih terjamin. Pada sisi lain, dengan kesadaran akan pentingnya konsumsi pangan yang beranekaragam, ketergantungan terhadap satu jenis pangan tertentu seperti beras, dapat dicegah dan situasi kerawanan pangan dapat dihindarkan.

Akan tetapi, hingga saat ini produk pangan lokal belum mampu menggeser komoditas pangan utama masyarkat seperti beras ataupun tepung terigu. Salah satu penyebabnya adalah rendahnya inovasi teknologi terhadap produk pangan lokal. Kalaupun mulai ada kreasi terhadap produk pangan lokal, jumlahnya masih dirasakan sangat terbatas sehingga pangan lokal belum mampu menarik minat konsumen untuk mengkonsumsinya. Di era globalisasi saat ini, permintaan konsumen akan produk pangan terus berkembang. Konsumen tidak hanya menuntut produk pangan bermutu, bergizi, aman, dan lezat, namun juga sesuai selera atau bahkan dapat membangkitkan efek gengsi atau berkelas bagi yang mengkonsumsinya.

Kecamatan Kokap memiliki luas wilayah 7.379,50 ha, merupakan kecamatan terluas di Kabupaten Kulon Progo, yaitu 12,59\% dari total luas wilayah Kabupaten Kulon Progo (58.627,512 ha) (BPS Kab. Kulon Progo, 2009). Kecamatan ini memiliki 5 desa, yang terdiri dari Desa Hargomulyo, Hargorejo, Hargowilis, Hargotirto, dan Kalirejo. Morfologinya didominasi oleh perbukitan denudasional dengan bukit-bukit yang mempunyai kemiringan lereng yang curam dengan proses erosi dan longsor yang berjalan dengan intensif.

Di wilayah utara yaitu Desa Hargotirto, Kalirejo, dan Hargowilis merupakan daerah perbukitan dan pegunungan denudasional dengan kemiringan lereng agak curam hingga curam dimana sebagian besar penggunaan lahannya masih berupa hutan dan pemukiman. Permasalahan yang dihadapi adalah kekurangan air ketika musim kemarau.

Hal ini dikarenakan tinggi muka air tanah yang begitu dalam sehingga sulit untuk menemukan sumber air tanah di wilayah ini. Disamping itu bentuk morfologi dari daerah ini yang sebagian besar berupa perbukitan dan pegunungan menyebabkan begitu dalamnya akuifer dan sulit untuk diakses oleh penduduk. Wilayah selatan yaitu Desa Hargorejo dan Hargomulyo merupakan daerah lereng tengah hingga lereng kaki yang wilayahnya berada di sekitar Waduk 
Sermo, yang tinggi muka air tanahnya tidak begitu dalam. Sebagian besar penduduk memanfaatkan air tanah untuk memenuhi kebutuhannya. Kondisi morfologi desa tersebut mempengaruhi kegiatan aktifitas penduduk yang ada di dalamnya, seperti kegiatan pertanian.

Tabel 1. Luas Desa Dirinci Menurut Penggunaan Lahan Di Kecamatan Kokap 2010 (Ha)

\begin{tabular}{lllllllll}
\hline No. & Nama Desa & $\begin{array}{c}\text { TSanah } \\
\text { Sawah }\end{array}$ & $\begin{array}{c}\text { Tanah } \\
\text { Kering }\end{array}$ & Bangunan & $\begin{array}{c}\text { Hutan } \\
\text { Rakyat }\end{array}$ & $\begin{array}{c}\text { Hutan } \\
\text { Negara }\end{array}$ & Lainnya & Jumlah \\
\hline 1. & Hargotirto & 0,00 & 160,70 & 671,70 & 515,00 & 0,00 & 124,33 & $1.471,73$ \\
2. & Kalirejo & 0,00 & 136,37 & 501,90 & 445,00 & 144,73 & 67,96 & $1.295,96$ \\
3. & Hargowilis & 7,90 & 117,15 & 743,95 & 215,94 & 215,94 & 246,96 & $1.547,84$ \\
4. & Hargorejo & 24,64 & 60,32 & 740,16 & 390,00 & 245,86 & 82,47 & $1.543,45$ \\
5. & Hargomulyo & 58,99 & 139,71 & 763,43 & 225,00 & 211,60 & 122,24 & $1.520,97$ \\
\hline
\end{tabular}

Sumber : Kecamatan Kokap dalam Angka 2010, BPS Kabupaten Kulon Progo

Seperti pada tabel 1. bahwa Desa Hargotirto dan Kalirejo merupakan desa yang berada pada bagian utara yang merupakan daerah perbukitan dan tinggi muka air tanah yang dalam sehingga pada penggunaan lahan tidak cocok untuk kegiatan pertanian sawah yang membutuhkan air yang melimpah untuk pemeliharannya, sehingga penggunaan lahan untuk tanah sawah sama sekali tidak ada (0 ha), penggunaan lahan didominasi untuk hutan rakyat dan bangunan yaitu pada Desa Hargotirto luas penggunaan lahan untuk hutan rakyat 515 ha dan luas penggunaan lahan bangunan 671,60 ha sedangkan pada Desa Kalirejo luas penggunaan lahan hutan rakyat 445 ha dan luas penggunaan lahan bangunan 501,90 ha. Tetapi sebaliknya pada Kecamatan Kokap bagian selatan yaitu Desa Hargorejo dan Hargomulyo yang memiliki kondisi geomorfologi datar sampai landai masih bisa digunakan untuk kegiatan pertanian. Desa Hagorejo dan Hargomulyo luas penggunaan untuk tanah sawah 24,64 ha dan 58,99 ha.

\begin{tabular}{|c|c|c|c|c|c|}
\hline No. & Desa & $\begin{array}{c}\text { Jumlah } \\
\text { Penduduk }\end{array}$ & $\begin{array}{c}\text { Padi } \\
\text { Sawah }\end{array}$ & Jagung & Ubi Kayu \\
\hline 1. & Hargotirto & 6.827 & - & - & 857 \\
\hline 2. & Kalirejo & 4.482 & - & - & 446 \\
\hline 3. & Hargowilis & 6.073 & - & - & 1.699 \\
\hline 4. & Hargorejo & 8.792 & 189 & 132 & 2.777 \\
\hline \multirow[t]{2}{*}{5.} & Hargomulyo & 7.401 & 678,4 & 84 & 2.156 \\
\hline & Jumlah & 33.575 & 867,4 & 216 & 7.927 \\
\hline
\end{tabular}

Sumber : Profil Kecamatan Kokap 2014, Kantor Kecamatan Kokap Kabupaten Kulon Progo

Pada tabel 2. menjelaskan tentang produksi pangan sumber karbohidrat yaitu padi sawah, jagung, dan ketela pohon di dua desa di utara (upland) yaitu Desa Hargotirto, Hargowilis dan Kalirejo tidak terdapat produksi pangan jenis padi sawah dan jagung tetapi memiliki hasil produksi pangan jenis ketela pohon yaitu pada Desa Hargotirto sebesar 857 ton,
Desa Kalirejo 446 ton, dan Desa Hargowilis 1.699 ton. Sedangkan pada desa sebelah selatan (down land) yaitu Desa Hargorejo dan Hargomulyo memiliki produksi pangan yang lebih beraneka ragam yaitu padi sawah, jagung, dan ketela pohon. Desa Hargorejo produksi padi sawah sebesar 189 ton, jagung 132 ton, dan ubi kayu 2.777 ton. 
Desa Hargomulyo produksi padi sawah sebesar 678,4 ton, jagung 84 ton, dan ubi kayu 2.156 ton.

Berdasarkan pada tabel 2. penduduk total pada tahun 2013 berjumlah 33.575 jiwa, jika semua penduduk dalam memenuhi kebutuhan pangan pokoknya memilih beras, sedangkan produksi total padi sawah 867,4 ton, setara dengan 544,2 ton beras (Konversi Gabah Menjadi Beras 62,74\% versi BPS dan Direktorat Jenderal Pengolahan dan Pemasaran Hasil Pertanian, Kementerian Pertanian) (Heriawan, 2016). Kebutuhan konsumsi beras pertahun dari total penduduk pada tahun 2013 adalah $3.820,8$ ton beras (kebutuhan beras 113,8 $\mathrm{kg} / \mathrm{kapita} /$ orang/tahun (BPS) (Ishaq, 2011) atau defisit beras sebanyak 3.276,6 ton. Maka dipastikan untuk memenuhi konsumsi beras domestik harus mendatangkan beras dari kecamatan lain atau dari daerah lain, karena produksi beras domestik tidak mencukupi. Disisi lain daerah ini memiliki komoditas pangan non beras yang produksinya besar seperti ketela pohon dan jagung tetapi masyarakat enggan mengkonsumsinya sebagai makanan pokok.

Gambaran ketersedian dan permintaaan pangan daerah tersebut mengindikasikan bahwa aspek ketahanan pangan yang berkaitan dengan keberlanjutan pada masyarakat belum sepenuhnya terpenuhi, yaitu dalam hal upaya penganekaragaman produksi dan konsumsi pangan yang bertujuan mengurangi tekanan pada satu macam produk pangan. Kebijakan tentang pangan lokal sebenarnya sudah dimulai pada dekade terakhir ini. Melalui Intruksi Bupati Kulon Progo Nomor 1 Tahun 2009, tentang penggunaan bahan baku pangan lokal pada acara pertemuan/rapat/kursus/pelatihan/kun jungan kerja lapangan, yang menginstruksikan kepada lembaga- lembaga yang ada di Kabupaten Kulon Progo untuk memasyarakatkan penggunaan pangan lokal dengan menyajikan makanan, snack, buah, sayuran, minuman yang berbahan baku pangan lokal pada acara tersebut. Namun demikian sepertinya masih terbatas jumlahnya dan intensitas sosialisasinya. Pangan lokal yang sering disebut memang sebenarnya banyak kita jumpai di sekeliling kita, tetapi seringkali luput dari minat untuk mengkonsumsinya. Maka dibutuhkan suatu kesadaran masyarakat (lingkup kecil yaitu rumah tangga sebagai unit perhatian terpenting pemenuhan kebutuhan pangan nasional maupun komunitas dan individu) untuk memulai merubah pola konsumsi pangan pokok yang hanya menggantungkan atau mengkonsumsi beras saja, menjadi pola konsumsi yang lebih beraneka. Yaitu dengan mengkonsumsi makananmakanan lokal sumber karbohidrat lain, sesuai dengan potensi yang dimiliki daerah masing-masing dan menjadikan pangan tersebut sebagai makanan pokok yang selalu dikonsumsi setiap hari atau kepentingannya setara dengan beras.

Tujuan penelitian ini untuk menganalisis intensitas konsumsi pangan lokal sumber karbohidrat non beras dalam pemenuhan energi dan protein sesuai angka yang dianjurkan Pola Pangan Harapan WKNPG VIII tahun 2004 dan melihat sejauh mana upaya masyarakat dalam usaha pencapaian ketahanan pangan melalui diversifikasi pangan sumber karbohidrat rumahtangga non tani dan tani.

\section{METODE PENELITIAN}

Metode penentuan lokasi penelitian kecamatan, desa dan dusun menggunakan teknik sampling purposif. Kecamatan Kokap dipilih karena memiliki wilayah yang paling luas dibandingkan kecamatan-kecamatan yang lain, yaitu $12,59 \%$ dari total luas wilayah Kabupaten 
Kulon Progo (58.627,512 ha). Wilayah tersebut memiliki produksi padi sawah yang paling kecil dibandingkan kecamatan lain, yaitu sebesar 769 ton sedangkan produksi jagung dan ketela pohon yang cukup besar yaitu masingmasing 219 ton dan 8.237 ton (Kabupaten Kulon Progo Dalam Angka 2014). Kemudian Kecamatan Kokap memiliki desa yang paling banyak mengalami kerawanan pangan (Maman Sugiri, 2014).

Pemilihan Desa Hargorejo karena desa tersebut tujuh tahun lalu pernah dilakukan program pertanian diversifikasi pangan pokok oleh LSM Impro Sola beserta BP3K dengan mengusahakan tanaman pangan lokal gembili (BP3K, 2013). Desa Hargorejo dipilih karena desa yang paling banyak memiliki komoditas umbi-umbian dan jagung dibanding desa yang lain di Kecamatan Kokap (Kantor Kecamatan Kokap, 2014). Kemudian pada Desa Hargorejo, ditentukan dua dusun untuk mewakili 16 dusun yang ada. Yaitu Dusun Ngulakan karena memiliki jumlah rumahtangga tani dan sekaligus tergabung dalam kelompok tani yang paling banyak yaitu 140 KK. Kemudian pada Dusun Ngulakan penggunaan lahan untuk kegiatan pertanian paling luas dibandingkan dusun lain yaitu seluas 8 ha (BP3K, 2013). Sedangkan untuk mewakili rumah tangga non tani dipilih Dusun Selo Timur karena memiliki jumlah rumahtangga non tani yang paling banyak yaitu 127 KK (BP3K, 2013). Penentuan besaran sampel pada rumahtangga tani dan non tani pada kedua dusun menggunakan rumus Slovin (Umar, 2003). Dari perhitungan didapat besaran sampel untuk masing-masing dusun berjumlah 60 KK.

Secara umum penelitian ini menganalisis intensitas konsumsi pangan lokal sumber karbohidrat non beras dalam pemenuhan energi dan protein sesuai angka yang dianjurkan Pola Pangan
Harapan WKNPG VIII tahun 2004 yang ada di Kecamatan Kokap. Produksi pangan lokal non beras pada Kecamatan Kokap terdiri dari ketela pohon dan jagung yang merupakan produksi unggulan. Tingkat konsumsi yang diteliti meliputi jenis pangan lokal sumber karbohidrat kelompok pangan padipadian (jagung) dan umbi-umbian (ketela pohon). Tetapi pada pembahasan ditampilkan juga pola konsumsi kelompok pangan padi-padian (beras) sebagai pangan pokok rumah tangga.

Tinjauan intensitas konsumsi terdiri dari kuantitas dan kualitas konsumsi pangan. Kuantitas konsumsi pangan ditinjau dari volume pangan yang dikonsumsi, sedangkan kualitas konsumsi pangan ditinjau dari konsumsi zat gizi (energi dan protein) yang terkandung dalam bahan pangan. Kedua hal itu digunakan untuk melihat apakah konsumsi pangan keluarga tersebut telah mencukupi kebutuhan yang layak untuk hidup sehat sesuai dengan sumbangan energi dan protein pada komposisi konsumsi pangan berdasarkan pola pangan harapan sesuai kelompok pangan sumber karbohidrat (padi-padian dan umbi-umbian).

Untuk melihat apakah konsumsi pangan sumber karbohidrat non beras telah mencukupi kebutuhan yang layak untuk hidup sehat, digunakan indikator konsumsi pangan berdasarkan pola pangan harapan sesuai kelompok pangan yang dianjurkan berdasarkan Widya Karya Nasional Pangan dan Gizi VIII tahun 2004. Tabel komposisi konsumsi pola pangan berdasarkan pola pangan harapan WKNPG VIII tahun 2004 disajikan dalam tabel 3.

Untuk mendapatan intensitas konsumsi pangan perkapita/g/hari berasal dari intensitas konsumsi pangan (kg/RT) dibagi jumlah anggota keluarga yang mengkonsumsi pangan. Setelah didapat hasil angka 
konsumsi/kapita/kg/hari kemudian dikonversikan dalam bentuk kalori dan protein untuk mengetahui kandungan gizi dalam setiap konsumsi per harinya berdasarkan Tabel Konversi Konsumsi Kalori Dan Protein Provinsi (BPS, 2012).

Tabel 3. Anjuran Komposisi Konsumsi Pangan Berdasarkan Pola Pangan Harapan Widya Karya Nasional Pangan dan Gizi VIII tahun 2004

\begin{tabular}{|c|c|c|c|c|c|c|c|c|}
\hline No. & $\begin{array}{c}\text { Kelompok } \\
\text { Pangan }\end{array}$ & $\begin{array}{l}\text { Gram } \\
\text { /hari }\end{array}$ & $\begin{array}{l}\text { Energi } \\
\text { (kkal) }\end{array}$ & $\begin{array}{c}\% \\
\text { AKE }\end{array}$ & $\begin{array}{l}\text { Protein } \\
(\mathrm{g})^{(1)}\end{array}$ & $\begin{array}{c}\% \\
\text { AKP }\end{array}$ & $\begin{array}{c}\% \\
\text { AKG }\end{array}$ & $\begin{array}{l}\text { Skor } \\
\text { PPH }\end{array}$ \\
\hline 1. & Padi-padian & 275 & 1.000 & 50 & 25,36 & 48,77 & 50 & 25 \\
\hline 2. & Umbi-umbian & 100 & 120 & 6 & 4,24 & 8,15 & 6 & 2,5 \\
\hline 3. & Pangan hewani & 150 & 240 & 12 & 1,78 & 3,42 & 12 & 24 \\
\hline 4. & $\begin{array}{l}\text { Minyak dan } \\
\text { lemak }\end{array}$ & 20 & 200 & 10 & 0,00 & 0 & 10 & 5 \\
\hline 5. & $\begin{array}{l}\text { Buah/biji } \\
\text { berminyak }\end{array}$ & 10 & 60 & 3 & 6,04 & 11,62 & 3 & 1 \\
\hline 6. & $\begin{array}{l}\text { Kacang- } \\
\text { kacangan }\end{array}$ & 35 & 100 & 5 & 11,71 & 22,52 & 5 & 10 \\
\hline 7. & Gula & 30 & 100 & 5 & 0,02 & 0,04 & 5 & 2,5 \\
\hline 8. & Sayur dan buah & 250 & 120 & 6 & 2,85 & 5,48 & 6 & 30 \\
\hline 9. & Lain-lain & - & 60 & 3 & 0,00 & 0 & 3 & 0 \\
\hline \multicolumn{2}{|c|}{ Jumlah } & & $2.000^{*}$ & 100 & $52^{*}$ & 100 & 100 & 100 \\
\hline
\end{tabular}

Setelah diketahui jumlah konsumsi energi dan protein kemudian dibandingkan angka kecukupan energi (AKE) dan angka kecukupan protein (AKP) berdasarkan angka anjuran komposisi konsumsi pangan berdasarkan pola pangan harapan Widya Karya Nasional Pangan dan Gizi VIII tahun 2004 yang akhirnya didapatkan keterangan konsumsi kelompok pangan lokal padipadian (jagung) dan umbi-umbian (ketela pohon) yang dikonsumsi apakah sudah sesuai anjuran atau belum. Penelitian ini dilakukan pada bulan Februari - Maret 2015.

\section{HASIL DAN PEMBAHASAN}

Hasil penelitian menunjukkan 60 responden rumahtangga nontani terdapat 10 orang yang mengkonsumsi ketela pohon dan dari 60 responden rumahtangga tani terdapat 26 orang yang mengkonsumsi pangan sumber karbohidrat non beras dengan, rincian 19 responden hanya mengkonsumsi ketela pohon saja dan 7 responden mengkonsumsi ketela pohon dan jagung.

Dari 10 responden rumahtangga non tani sebanyak 8 responden angka intensitas konsumsi pangan lokal sumber karbohidrat non beras (ketela pohon) sangat kecil, atau kurang dari angka yang direkomendasikan WKNPG VIII 2004 yaitu sebesar $120 \mathrm{kkal} /$ kapita/hari energi dan 3,12 g/kapita/hari protein. Yaitu pada intensitas konsumsi ketela pohon yang menyumbang energi dan protein sebesar 46,75 kkal dan 0,30 g/kapita/hari (sebanyak 7 responden). Dan pada intensitas konsumsi ketela pohon yang menyumbang energi dan protein sebesar 93,49 kkal dan 0,61 g/kapita/hari (sebanyak 1 responden). Sedangkan 2 responden angka konsumsi melebihi angka yang direkomendasikan. Yaitu masing-masing dengan sumbangan energi dan protein sebesar $654,5 \mathrm{kkal}$ dan 4,25 g/kapita/hari dan pada sumbangan energi dan protein sebesar 140,25 kkal dan 0,91 g/kapita/hari. Rumahtangga non 
tani yang mengkonsumsi ketela pohon maka secara sadar ataupun tidak sadar telah menerapkan konsumsi pola pangan harapan berdasarkan anjuran WKNPG VIII tahun 2004 yaitu idealnya pada konsumsi per kapita per hari hendaknya mengkonsumsi pangan sumber karbohidrat dari kelompok padi-padian (beras) dan umbi-umbian (ketela pohon).

Tabel 4. Sebaran Tingkat Kecukupan Energi dan Protein Konsumsi Beras dan Ketela Pohon Rumahtangga Non Tani Berdasarkan WKNPG 2004 (Skor Ideal Padi-Padian + Umbi-Umbian sebesar $1.120 \mathrm{kkal}$ dan 29,60 g/kapita/hari)

\begin{tabular}{|c|c|c|c|c|c|c|}
\hline \multirow{2}{*}{$\begin{array}{c}\text { Nama } \\
\text { Responden }\end{array}$} & \multicolumn{2}{|c|}{ Beras } & \multicolumn{2}{|c|}{ Ketela pohon } & \multirow{2}{*}{$\begin{array}{l}\text { Energi Total } \\
\text { (Beras dan } \\
\text { Ketela pohon) } \\
\text { (kkal/kap/hr) }\end{array}$} & \multirow{2}{*}{$\begin{array}{l}\text { Protein Total } \\
\text { (Beras dan } \\
\text { Ketela pohon) } \\
\text { (kkal/kap/hr) }\end{array}$} \\
\hline & $\begin{array}{c}\text { Energi } \\
\text { (kkal/kap/hr) }\end{array}$ & $\begin{array}{c}\text { Protein } \\
(\mathrm{g} / \text { kap/hr) }\end{array}$ & $\begin{array}{c}\text { Energi } \\
\text { (kkal/kap/hr) }\end{array}$ & $\begin{array}{c}\text { Protein } \\
(\mathrm{g} / \mathrm{kap} / \mathrm{hr})\end{array}$ & & \\
\hline 12 & 603,66 & 14,12 & 46,75 & 0,30 & 650,41 & 14,42 \\
\hline 13 & 452,75 & 10,59 & 46,75 & 0,30 & 499,5 & 10,89 \\
\hline 24 & 603,66 & 14,12 & 46,75 & 0,30 & 650,41 & 14,42 \\
\hline 27 & 603,66 & 14,12 & 46,75 & 0,30 & 650,41 & 14,42 \\
\hline 29 & 1.811 & 42,37 & 93,5 & 0,61 & $1.904,5$ & 42,98 \\
\hline 30 & 905,5 & 21,18 & 46,75 & 0,30 & 952,25 & 21,48 \\
\hline 47 & 603,66 & 14,12 & 46,75 & 0,30 & 650,41 & 14,42 \\
\hline 48 & 905,5 & 21,18 & 46,75 & 0,30 & 952,25 & 21,48 \\
\hline 51 & 603,66 & 14,12 & 654,5 & 4,25 & 650,41 & 14,42 \\
\hline 53 & 905,5 & 21,18 & 140,45 & 0,91 & $1.045,95$ & 22,09 \\
\hline
\end{tabular}

Tetapi jika dilihat dari sebaran tingkat kecukupan energi dan protein konsumsi beras dan ketela pohon rumahtangga non tani dari 10 responden sebanyak 8 responden belum mencapai angka konsumsi ideal. Adapun terdapat 1 responden yang hampir mencapai angka ideal yaitu sebesar 1.045,95 kkal dan 22,09 g/kapita/hari (93,38\% tingkat kecukupan energi dan 74,62\% tingkat kecukupan protein). Kemudian terdapat 1 responden yang angka konsumsinya melebihi angka anjuran yaitu sebesar 1.904,5 kkal dan 42,98 g/kapita/hari atau mengalami kelebihan sebesar 70,04\% tingkat kecukupan energi dan 45,20\% tingkat kecukupan protein konsumsi sumber karbohidrat dari padi-padian dan umbiumbian.

Pada rumahtangga tani dari 26 responden yang mengkonsumsi ketela pohon, terdapat 15 responden $(57,69 \%)$ kecukupan energi dan protein dari sumbangan konsumsi ketela pohon melebihi angka yang dianjurkan dan 11 responden $(42,31 \%)$ kecukupan energi dan protein sumbangan dari konsumsi ketela pohon masih dibawah angka yang dianjurkan. Kontribusi intesitas konsumsi ketela pohon terhadap pemenuhan energi dan protein pada rumahtangga tani terbesar menyumbang energi dan protein sebesar 327,25 kkal dan 2,12 g/kapita/hari. Kemudian intensitas konsumsi terkecil menyumbang energi dan protein sebesar 31,17 kkal dan 0,20 g/kapita/hari.

Adapun dari ke-19 responden yang telah dirangkum, konsumsi kelompok pangan padi-padian (beras) dan umbiumbian (ketela pohon) terdapat 3 responden yang konsumsi energi dan protein masih dibawah angka anjuran, yaitu sebesar 999 kkal dan 21,78 $\mathrm{g} /$ kapita/hari atau capaian konsumsinya baru mencapai $89,19 \%$ dan 73,58\%. Dan terdapat responden yang hampir mencapai skor ideal yaitu pada tingkat kecukupan energi dan protein sebesar 1.045,75 kkal dan 22,09 g/kaita/hari sebanyak 4 responden, kecukupan energi dan protein sebesar 1.066,02 kkal dan 24,41 g/kaita/hari sebanyak 1 responden dan kecukupan energi dan protein sebesar 1.103,16 kkal dan 25,01 $\mathrm{g} /$ kapita/hari sebanyak 3 responden. Dan 
terdapat 5 responden yang angka kecukupan energi sudah mencapai skor ideal untuk konsumsi sumber karohidrat dari padi-padian dan umbi-umbian.
Sementara terdapat 3 responden yang angka kecukupan energi melebihi angka ideal.

Tabel 5. Sebaran Tingkat Kecukupan Energi dan Protein Konsumsi Beras dan Ketela Pohon Rumahtangga Tani Berdasarkan WKNPG 2004 (Skor Ideal Padi-Padian + UmbiUmbian sebesar $1.120 \mathrm{kkal}$ dan 29,60 g/kapita/hari)

\begin{tabular}{|c|c|c|c|c|c|c|}
\hline \multirow[b]{2}{*}{$\begin{array}{c}\text { Nama } \\
\text { Responden }\end{array}$} & \multicolumn{2}{|c|}{ Beras } & \multicolumn{2}{|c|}{ Ketela pohon } & \multirow[b]{2}{*}{$\begin{array}{c}\text { Energi total } \\
\text { (beras dan ketela } \\
\text { pohon) } \\
\text { (kkal/kap/hr) }\end{array}$} & \multirow{2}{*}{$\begin{array}{l}\text { Protein total } \\
\text { (beras dan } \\
\text { ketela } \\
\text { pohon) } \\
(\mathrm{g} / \mathrm{kap} / \mathrm{hr})\end{array}$} \\
\hline & $\begin{array}{c}\text { Energi } \\
\text { (kkal/kap/hr) }\end{array}$ & $\begin{array}{l}\text { Protein } \\
\text { (g/kap/hr) }\end{array}$ & $\begin{array}{c}\text { Energi } \\
\text { (kkal/kap/hr) }\end{array}$ & $\begin{array}{c}\text { Protein } \\
\text { (g/kap/hr) }\end{array}$ & & \\
\hline 4 & 905,5 & 21,18 & 140,25 & 0,91 & $1.045,75$ & 22,09 \\
\hline 6 & $1.056,41$ & 24,71 & 280,5 & 1,82 & $1.336,91$ & 26,53 \\
\hline 12 & $1.056,41$ & 24,71 & 46,75 & 0,30 & $1.103,16$ & 25,01 \\
\hline 13 & 905,5 & 21,18 & 140,25 & 0,91 & $1.045,75$ & 22,09 \\
\hline 19 & 905,5 & 21,18 & 327,25 & 2,12 & $1.232,75$ & 23,3 \\
\hline 21 & 905,5 & 21,18 & 93,5 & 0,60 & 999 & 21,78 \\
\hline 29 & $1.086,6$ & 25,42 & 46,75 & 0,30 & $1.133,35$ & 25,72 \\
\hline 32 & $1.086,6$ & 25,42 & 46,75 & 0,30 & $1.133,35$ & 25,72 \\
\hline 33 & $1.086,6$ & 25,42 & 46,75 & 0,30 & $1.133,35$ & 25,72 \\
\hline 36 & $1.056,41$ & 24,71 & 280,9 & 1,82 & $1.337,31$ & 26,53 \\
\hline 44 & 905,5 & 21,18 & 93,5 & 0,60 & 999 & 21,78 \\
\hline 46 & $1.056,41$ & 24,71 & 46,75 & 0,30 & $1.103,16$ & 25,01 \\
\hline 47 & $1.086,6$ & 25,42 & 46,75 & 0,30 & $1.133,35$ & 25,72 \\
\hline 52 & 905,5 & 21,18 & 93,5 & 0,60 & 999 & 21,78 \\
\hline 53 & 905,5 & 21,18 & 140,25 & 0,91 & $1.045,75$ & 22,09 \\
\hline 54 & 905,5 & 21,18 & 140,25 & 0,91 & $1.045,75$ & 22,09 \\
\hline 56 & 905,5 & 21,18 & 280,5 & 1,82 & 1.186 & 23 \\
\hline 57 & $1.056,41$ & 24,71 & 46,75 & 0,30 & $1.103,16$ & 25,01 \\
\hline 60 & $1.034,85$ & 24,21 & 31,17 & 0,20 & $1.066,02$ & 24,41 \\
\hline
\end{tabular}

Tabel 6. Sebaran Tingkat Kecukupan Energi dan Protein Konsumsi Beras, Jagung (Jagung basah dengan kulit) dan Ketela Pohon Responden Rumahtangga Tani Berdasarkan WKNPG 2004 (Skor Ideal Padi-Padian + Umbi-Umbian sebesar 1.120 kkal dan 29,60 g/kapita/hari)

\begin{tabular}{|c|c|c|c|c|c|c|c|c|c|c|}
\hline \multirow{2}{*}{$\begin{array}{c}\text { Nama } \\
\text { Respo } \\
\text { nden }\end{array}$} & \multicolumn{2}{|c|}{ Beras } & \multicolumn{2}{|c|}{ Jagung } & \multicolumn{2}{|c|}{$\begin{array}{c}\text { Energi } \\
\text { Total/Padi- } \\
\text { padian (beras } \\
\text { dan jagung) }\end{array}$} & \multicolumn{2}{|c|}{ Ketela Pohon } & \multicolumn{2}{|c|}{$\begin{array}{c}\text { Energi } \\
\text { Total/padi- } \\
\text { padian (beras } \\
\text { dan jagung) dan } \\
\text { ketela pohon }\end{array}$} \\
\hline & $\begin{array}{c}\text { Energi } \\
\text { (kkal/ } \\
\text { kap/ } \\
\text { hr) }\end{array}$ & $\begin{array}{c}\text { Protei } \\
\text { n } \\
(\mathrm{g} / \mathrm{kap} \\
/ \\
\mathrm{hr}) \\
\end{array}$ & $\begin{array}{c}\text { Energi } \\
\text { (kkal/ } \\
\text { kap/ } \\
\text { hr) }\end{array}$ & $\begin{array}{l}\text { Protei } \\
\text { n } \\
(\mathrm{g} / \mathrm{kap} \\
/ \mathrm{hr})\end{array}$ & $\begin{array}{c}\text { Energi } \\
\text { (kkal/ } \\
\text { kap/hr) }\end{array}$ & $\begin{array}{l}\text { Protei } \\
\text { n } \\
(\mathrm{g} / \mathrm{kap} \\
\text { /hr) }\end{array}$ & $\begin{array}{l}\text { Energi } \\
\text { (kkal/ } \\
\text { kapi/ } \\
\text { hr) }\end{array}$ & $\begin{array}{c}\text { Protei } \\
\text { n } \\
(\mathrm{g} / \mathrm{kap} \\
/ \\
\mathrm{hr}) \\
\end{array}$ & $\begin{array}{c}\text { Energi } \\
\text { (kkal/ } \\
\text { kap/ } \\
\text { hr) }\end{array}$ & $\begin{array}{c}\text { Protei } \\
\text { n } \\
(\mathrm{g} / \mathrm{kap} \\
/ \\
\mathrm{hr}) \\
\end{array}$ \\
\hline 1 & $1.086,6$ & 25,42 & 10,32 & 0,32 & $1.096,92$ & 25,74 & 140,25 & 0,91 & $1.237,17$ & 26,65 \\
\hline 2 & $1.056,41$ & 24,71 & 25,8 & 0,82 & $1.082,21$ & 25,53 & 280,5 & 1,82 & $1.362,71$ & 27,35 \\
\hline 3 & $1.086,6$ & 25,42 & 20,64 & 0,56 & $1.107,24$ & 25,98 & 327,25 & 2,12 & $1.434,49$ & 28,10 \\
\hline 8 & $1.034,85$ & 24,21 & 22,11 & 0,70 & $1.056,96$ & 24,91 & 218,16 & 1,41 & $1.275,12$ & 26,32 \\
\hline 10 & $1.086,6$ & 25,42 & 10,32 & 0,32 & $1.096,92$ & 25,74 & 327,25 & 2,12 & $1.424,17$ & 27,86 \\
\hline 11 & 905,5 & 21,18 & 30,96 & 0,98 & 936,46 & 22,16 & 327,25 & 2,12 & $1.263,71$ & 24,28 \\
\hline 18 & $1.018,68$ & 23,83 & 19,35 & 0,61 & $1.038,03$ & 24,44 & 280,5 & 1,82 & $1.318,53$ & 26,26 \\
\hline
\end{tabular}


Pada kontribusi intensitas konsumsi jagung (jagung basah dengan kulit) terhadap pemenuhan energi dan protein menyubang sebesar 30,96 kkal dan 0,98 g/kapita/hari. Intensitas konsumsi terkecil menyumbang energi dan protein sebesar 10,32 kkal dan 0,32 g/kapita/hari. Kemudian angka konsumsi total yang telah dirangkum pada 7 orang responden, kelompok pangan padi-padian (beras dan jagung) dan umbi-umbian (ketela pohon), sebanyak 7 responden $(100 \%)$ tingkat konsumsi energi sudah melampaui angka yang dianjurkan.

Intensitas konsumsi pangan sumber karbohidrat rumahtangga tani lebih besar dari pada rumahtangga non tani dikarenakarena memang rumahtangga tani dalam bekerja lebih banyak mendayagunakan energi fisiknya sehingga kebutuhan akan energi lebih besar untuk kebutuhan bahan bakar aktivitas fisik/bekerja. Kemudian rumahtangga tani ini sendiri merupakan produsen dari tanaman padi, ketela, dan jagung sehingga akses terhadap pangan tersebut sangat terjangkau. Pola konsumsi rumahtangga tani masih lebih sederhana dibandingkan dengan rumahtangga non tani. Konsep mengutamakan makan makanan yang dimasak di rumah masih sangat kuat, hal ini selain pola hidup yang sederhana juga sebagai akibat pola pekerjaan petani yang tidak terlalu kompleks, sehingga masih memunginkan mereka pulang untuk makan siang di rumah. Atau yang terlihat jelas, pola pekerjaan wanita tani juga tidak kompleks seperti pola pekerjaan wanita non tani. Para ibu masih punya waktu untuk memasak dirumah untuk kebutuhan keluarganya dan masih punya waktu untuk mengantarkan makanan untuk suaminya di sawah. Berbeda halnya dengan rumahtangga non tani yang angka konsumsi pangan sumber karbohidrat lebih rendah bahwa terdapat kecenderungan pengeluaran untuk konsumsi pangan jadi lebih tinggi. Hal ini dikarenakan konsekuensi pola pekerjaan rumahtangga non tani yang lebih kompleks dan lebih mementingkan efisiensi waktu beraktifitas. Seperti lebih memilih membeli nasi rames di luar/warung untuk kebutuhan sarapan ataupun makan siang.

Melihat jumlah responden yang mengkonsumsi pangan sumber karbohidrat non beras pada rumahtangga non tani dan tani tersebut masih sangat kecil. Yaitu pada rumahtangga non tani dari 60 responden hanya 10 responden saja yang mengkonsumsi sedangkan pada rumahtangga tani dari 60 responden terdapat 26 responden yang mengkonsumsi. Padahal dengan mengkonsumsi pangan sumber karbohidrat non beras, pemenuhan energi dan protein dapat sesuai dengan angka yang dianjurkan. Mengkonsumsi pangan sumber karbohidrat non beras misalnya ketela pohon ataupun jagung merupakan konsumsi pangan berdasarkan pola pangan harapan dimana semakin bervariasinya jenis pangan yang dikonsumsi maka komposisi pangan tersebut dianggap ideal. Sebagai contoh pada rumahtangga non tani (Tabel 4 . Responden 53), pada salah satu responden sumbangan energi dan protein dari konsumsi beras sebesar 905,5 kkal dan 21,18 g/kapita/hari (baru mencapai $80,84 \%$ tingkat kecukupan energi dan $71,55 \%$ tingkat kecukupan protein dari angka konsumsi energi dan protein anjuran pada kelompok pangan padipadian dan umbi-umbian sebesar 1.120 kkal dan 29,60 g/kapita/hari). Dengan mengkonsumsi ketela pohon yang memiliki kandungan energi dan protein sebesar 140,45 kkal dan 0,91 $\mathrm{g} /$ kapita/hari, maka kecukupan energi dan proteinnya menjadi 1.045,95 kkal dan 22,09 g/kapita/hari (bertambah menjadi 93,38\% tingkat kecukupan energi dan $74,62 \%$ tingkat kecukupan protein) atau 
konsumsi ketela pohon tersebut menyumbang energi dan protein sebesar $12,54 \%$ kkal dan 3,07\% dari angka konsumsi energi dan protein yang dianjurkan pada kelompok pangan padipadian dan umbi-umbian.

Begitu juga pada salah satu contoh responden rumahtangga tani, dimana responden tersebut mengkonsumsi sumber karbohidrat tidak hanya dari beras saja yaitu ketela pohon dan jagung (Tabel 6. Responden 11). Dengan mengkonsumsi pangan sumber karbohidrat dari padi-padian (beras dan jagung) dan umbi-umbian (ketela pohon) sumbangan energi dan protein dari pangan tersebut sebesar $1.263,71 \mathrm{kkal}$ dan 24,28 g/kapita/hari/ atau tingkat konsumsi energi sebesar $112 \%$ dan tingkat konsumsi protein 82,02\%. Melihat dari sumbangan pangan sumber karbohidrat non beras dalam pemenuhan kebutuhan energi dan protein tersebut (yang berasal dari ketela dan jagung) memang terdapat angka tingkat kecukupan energi lebih besar dari pada angka yang dianjurkan sedangkan angka tingkat kecukupan protein malah dibawah/belum mencapai angka yang dianjurakan.

Hal ini dikarenan angka ideal yang dianjurakan terebut berasal dari kelompok pangan padi-padian dan umbiumbian yang terdiri dari berbagai macam jenis pangan. Seperti pada kelompok pangan padi-padian yang terdiri dari beras, beras ketan, jagung basah dengan kulit, jagung pipilan, tepung beras, tepung jagung, tepung terigu dan lain-lain. Pada kelompok pangan umbi-umbian yang terdiri dari ketela pohon, ketela rambat, sagu, talas, kentang, gaplek, tepung gaplek, tepung ketela pohon dan lain-lain. Angka konsumsi ideal kelompok pangan padi-padian tiap $275 \mathrm{~g}$ /hari mengandung energi dan protein sebesar $1.000 \mathrm{kkal}$ dan 25,36 g/kapita/hari. Sedangkan angka konsumsi ideal pada kelompok umbiumbian tiap $100 \mathrm{~g} /$ hari mengandung energi dan protein sebesar $120 \mathrm{~g}$ dan 4,24 $\mathrm{g} /$ kapita/hari. Angka tersebut didapat dari rata-rata kandungan energi dan protein dari kelompok pangan padipadian dan juga kelompok umbi-umbian. Maka angka konsumsi energi dan protein seseorang dapat mencapai angka ideal jika diasumsikan mengkonsumsi semua jenis pangan dari kelompok pangan padipadian dan kelompok pangan umbiumbian tiap gram tertentu sesuai yang dianjurkan per harinya. Tetapi setidaknya dengan mengkonsumsi pangan sumber karbohidrat yang berasal tidak hanya dari beras saja atau juga mengkonsumsi jagung dan umbi-umbian (ketela pohon) maka pola konsumsi pangan tersebut mengindikasikan ke arah pola pangan ideal.

Untuk mencapai pola pangan ideal, sangat perlu untuk menyajikan pangan umbi-umbian di meja makan setiap harinya. Dan seharusnya pangan umbiumbian tersebut tingkat kepentingan konsumsinya sepadan dengan tingkat kepentingan konsumsi beras bagi rumahtangga. Karena setiap hari selalu membutuhkan umbi-umbian guna mencapai pola pangan harapan yang telah dianjurkan. Tetapi sayangnya tidak mudah merubah mindset dan kebiasaan masyarakat yang sudah terlanjur nyaman dengan konsumsi pangan beras.

Rendahnya konsumsi pangan non beras khususnya ketela pohon dan jagung seiring dengan semakin maraknya jenis pangan olahan yang siap saji dan praktis, serta dapat diperoleh dengan mudah. Belum lagi adanya perubahan gaya hidup masyarakat yang jelas berpengaruh pula pada gaya makan. Mungkin orang akan gengsi mengkonsumsi ketela pohon dan jagung karena komoditas tersebut sudah mempunyai trade mark sebagai barang inferior, yang hanya cocok untuk kalangan bawah.

Dalam kegiatan upacara-upacara kebudayaan misalnya seperti selamatan 
ataupun hajatan, masyarakat yang memiliki hajat sangat jarang atau tidak ada yang menghidangkan pangan seperti ketela ataupun jagung sebagai pangan pokok untuk mendampingi lauk dan sayur. Kalaupun ada hanya sebatas makanan olahan seperti snack ataupun kue yang terbuat dari umbi-umbian ataupun jagung. Masyarakat mengalihkan fungsi ketela pohon dan jagung, tidak lagi sebagai makanan pokok tetapi sebagai makanan selingan atau snack, sehingga jumlah yang dikonsumsi juga sangat terbatas. Dari hasil wawancara tersebut menunjukkan bahwa pangan lokal seperti ketela pohon dan jagung telah ditinggalkan oleh masyarakat rumahtangga non tani dan tani, dan pangan global seperti mie (mie instan) dan terigu/gandum menunjukkan kebalikannya.

Umbi-umbian seperti ketela pohon menjadi fokus pada penelitian ini karena ketela pohon nilai kalorinya mendekati nilai kalori pada beras dan potensi keberadaan ketela pohon di Indonesia cukup besar. Ketela pohon dapat tumbuh di tanah yang kurang subur sekalipun dengan perawatan yang tidak terlalu rumit. Menurut Dewanti dkk, (2002), ketela pohon adalah bahan pangan terpenting ke-4 setelah beras, jagung, dan kedelai. Selain itu, ketela pohon juga sebagai bahan makanan pokok terbanyak ke-3 setelah padi dan jagung. Indonesia adalah negara pengekspor ketela pohon terbesar kedua setelah Thailand. Hal ini merupakan potensi ketela pohon yang cukup bagus untuk mendampingi beras dalam rangka mempertahankan ketahanan pangan Indonesia.

Dalam konsep ketahanan pangan, diversifikasi pangan merupakan salah satu syarat untuk mencapai ketahanan pangan yang tangguh. Melalui penataan pola konsumsi yang tidak tergantung pada satu sumber pangan, memungkinkan masyarakat dapat menetapkan pangan pilihan sendiri dan diproduksi sendiri (diproduksi dalam negeri). Sehingga ketergantungan pada satu jenis komoditas pangan dapat dihindari.

Diversifikasi konsumsi pangan rumahtangga merupakan salah satu pilar ketahanan pangan nasional. Langkah ini hanya membutuhkan waktu yang lebih pendek jika dibandingkan dengan program lain, seperti ekstensifikasi dan intensifikasi. Diversifikasi konsumsi pangan rumahtangga juga mendorong rumahtangga lebih kreatif dalam memanfaatkan lahan yang ada dengan menanam tanaman yang dapat menjadi bahan makanan pokok selain padi, seperti ketela, jagung dan umbi-umbian lainnya.

\section{SIMPULAN}

Pertama, rumahtangga non tani dan tani belum menerapkan diversifikasi pangan dalam konsumsi sehari-hari. Hal ini terbukti dri 60 responden rumahtangga nontani hanya 10 orang dan dari 60 responden rumahtangga tani hanya terdapat 26 yang mengkonsumsi pangan sumber karbohidrat non beras.

Kedua, dari 10 responden rumahtangga non tani sebanyak 8 responden intensitas konsumsi pangan lokal sumber karbohidrat non beras (ketela pohon) sangat kecil, atau kurang dari angka yang direkomendasikan. Sedangkan 2 responden angka konsumsi melebihi angka yang direkomendasikan. Dilihat dari sebaran tingkat kecukupan energi dan protein konsumsi padi-padian (beras) dan umbi-umbian (ketela pohon) dari 10 responden sebanyak 9 responden belum mencapai angka konsumsi ideal. Adapun terdapat 1 responden yang hampir mencapai angka ideal. Kemudian terdapat 1 responden yang angka konsumsinya melebihi angka anjuran.

Ketiga, pada rumahtangga tani dari 26 responden yang mengkonsumsi ketela pohon, terdapat 15 responden 
Intensitas konsumsi pangan lokal sumber karbohidrat non beras (ketela pohon) melebihi angka yang dianjurkan dan 11 responden masih dibawah angka yang dianjurkan. Adapun dari ke-19 responden yang telah dirangkum, konsumsi kelompok pangan padi-padian (beras) dan umbi-umbian (ketela pohon) 3 responden yang angka kecukupan energi melebihi angka ideal, 5 responden yang angka kecukupan energi sudah mencapai skor ideal, 8 responden hampir mencapai skor ideal, 3 responden yang konsumsi masih dibawah angka anjuran.

Keempat, angka konsumsi total yang telah dirangkum pada 7 orang responden, kelompok pangan padipadian (beras dan jagung) dan umbiumbian (ketela pohon), tingkat konsumsi energi dan protein sudah melampaui angka yang dianjurkan.

\section{REKOMENDASI}

Untuk merubah pola pangan masyarakat yang hanya bergantung pada satu jenis pangan perlu digalakan diintensifkan kampanye diversifikasi pangan sumber karbohidrat non beras seperti penyuluhan pada pertemuan rutin warga di tiap-tiap RT, harapannya dalam rumahtangga melalui orang tua dapat mengenalkan dan membudayakan putraputrinya mengkonsumsi pangan lokal sumber karbohidrat non beras. Kemudian perlu digencarkannya iklan-iklan layanan masyarakat tentang diversifikasi pangan melalui media masa seperti siaran radio, siaran di TV daerah dan pemasangan baliho atau poster yang berisikan ajakan mengkonsumsi pangan non beras di lingkunagan kantor, sekolah dan kampus, dinas dan titik-titik keramaian daerah. Harapannya semakin seringnya pesan yang digalakkan menimbulkan kesadaran dari masyarakat untuk merubah pola konsumsi pangannya. $\underline{\text { Tesis }}$

Anugerah, G.I. 2012. Diversifikasi Konsumsi Pangan Rumah Tangga Pedesaan Di Desa Sukolilo Kecamatan Wajak Kabupaten Malang. Tesis tidak diterbitkan. Situbondo: Fakultas Pertanian Universitas Abdurachman Saleh Situbondo.

\section{Prociding}

Musriyadi N, Ketut S, Apri A, Nusril. 2010. Marketed Surplus Ubi Jalar (Ipomoea Batatas) dan Dampaknya Terhadap Ketersediaan Pangan Nonberas di Provinsi Bengkulu. Prosiding Semirata Bidang IlmuIlmu Pertanian BKS-PTN Wilayah Barat Tahun 2010. 739-748.

\section{$\underline{\text { Buku }}$}

Arifin, B. 1997. Manajemen Krisis Pangan Dalam 30 Tahun Peran Bulog dalam Ketahanan Pangan. Jakarta: Bulog.

Badan Ketahanan Pangan dan Penyuluhan. 2013. Angka Aktual Skor Pola Pangan Harapan Konsumsi Pangan Penduduk Berdasarkan Data SUSENAS Propinsi D.I. Yogyakarta Tahun 2013.

BP3K. 2013. Hasil Penilaian Kemampuan Kelompok Tani Kecamatan Kokap Kabupaten Kulon Progo Tahun 2013. BP3K.

BPS. 2009. Kulon Progo dalam Angka 2009.

BPS. 2010. Kecamatan Kokap dalam Angka 2010.

BPS. 2012. Konsumsi Kalori Dan Protein Penduduk Indonesia Dan Provinsi. Buku 2.

Dewanti, R., N. Andarwulan, dan N.S. Palupi. 2002. Pangan Lokal Sumber Karbohidrat. Bogor: Fateta IPB.

Kantor Kecamatan Kokap. 2014. Profil Kecamatan Kokap 2014. 
Umar Husein. 2003. Studi Kelayakan dalam Bidang Jasa. Jakarta: Gramedia

\section{Artikel Jurnal}

Hastarini, DA. 2010. Kajian Ketahanan Pangan di Indonesia. Jurnal Media Ekonomi dan Manajemen. 21(1): 5160.

Heriawan, dkk, 2016. Kebijakan Swasembada Pangan Berkelanjutan: Komponen Strategis Dalam Perspektif Masyarakat Ekonomi Asean 2015. Badan Penelitian Dan Pengembangan PertanianIndonesian Agency for Agricultural Research and Development (IAARD) Press.

http://pse.litbang.pertanian.go.id/i nd/pdffiles/swasembada_pangan_

2015.pdf

[Diakses 25 Oktober 2016 pukul 21:30]

Ishaq, I,. 2011. Konsumsi dan Strategi Pemenuhan Kebutuhan Beras pada 2015 di Jawa Barat. Balai Pengkajian Teknologi Pertanian Jawa Barat. Iptek Tanaman Pangan. 6(2) - 2011. [Diakses 13 Oktober 2016 pukul 21:30]

Maman Sugiri. 2015. KP4K Anggarkan

Penanganan Desa Rawan Pangan.

http://jogja.antaranews.com/berita /320983/kp4k-anggarkanpenanganan-desa-rawan-pangan [Diakses 13 Mei 2015 pukul 20:03]

Moniharapon GJ, Martha T, Johanna ML. 2013. Perubahan Pola Konsumsi

Pangan Rumah Tangga dari Mengkonsumsi Pangan Lokal ke Pangan Beras pada Kecamatan Leitimur Selatan Kota Ambon. Jurnal Agrilan. 1(4): 83-93.

Suyastiri, N. M. 2008. Difersifikasi Konsumsi Pangan Pokok Berbasis Potensi Lokal dalam Mewujudkan Ketahanan Pangan Rumahtangga di
Pedesaan Gunung Kidul. Jurnal Ekonomi Pembangunan. 13(1): 5160.

Yunita dan Riswani. 2013. Behavior of Household Rice Consumption in Different Income Level. International Journal of Humanities and Management Sciences (IJHMS). 1(3): 220-224. 